\title{
Special section: Offshoring, immigration and the labour market: a micro-level perspective
}

\section{Editorial}

\author{
Davide Castellani ${ }^{1} \cdot$ Maria Luisa Mancusi $^{2}$. \\ Grazia D. Santangelo ${ }^{3}$ - Antonello Zanfei $^{4}$
}

Recent years have seen remarkable changes in the nature of trade and foreign direct investment (FDI) flows. A keyword that is often used to summarize the multi-facet aspects of this transformation is "offshoring" which can be broadly defined as firms' allocation of economic activities to another country, either by obtaining goods and services from unaffiliated foreign companies, or by investing in the creation of joint ventures or foreign affiliates (the latter being identified as "captive offshoring"). Indeed, offshoring has stretched national boundaries and broadened firms' perspective, making business an international issue. As a result, the international involvement of firms has increased over time, and multinational enterprises have become key players in this globalized modern scenario. The

Antonello Zanfei

antonello.zanfei@uniurb.it

Davide Castellani

davide.castellani@unipg.it

Maria Luisa Mancusi

marialuisa.mancusi@unicatt.it

Grazia D. Santangelo

grsanta@unict.it

1 Department of Economics, University of Perugia, Via Pascoli, 20, 06123 Perugia, Italy

2 Department of Economics and Finance, Catholic University (Milan), L.go Gemelli 1, 20123 Milan, Italy

3 Department of Political and Social Sciences, University of Catania, Via Vittorio Emanuele II, 8, 95131 Catania, Italy

4 Department of Economics, Society and Politics, University of Urbino, Via Saffi 42, 61029 Urbino, Italy 
process has been accelerated by a significant reduction in trade barriers, obstacles to factor mobility, and communication costs.

One major issue in the policy and literature debate following the quantitative growth of offshoring has to do with its effects on wages and employment in the home country. Indeed, fears that offshoring may cause job losses and hollowing-out of valuable knowledge have emerged over the past two decades (Kotabe 1990; ETAN 1998; Levinson 2011). Such fears further add up to those that increasing competition by immigrant workers in the domestic labour market may reduce domestic wages and increase natives' unemployment rates (Okkerse 2008).

The perception of potentially negative effects of both offshoring and immigration on employment and wages of native workers has been feeding a growing concern in the public opinion on the alleged negative effects of globalisation. Kaldor et al. (2003) have documented the emergence in civil society of a number of variegated and often contradictory positions militating against globalisation, and has dubbed them as "rejectionists"-i.e.in favour of greater protection of national economies and of stricter regulation on both offshoring and immigration. Although these positions have had limited consideration in the academic debate, they have been very influential on public policies since the early 2000's, leading to more restrictive measures vis à vis FDIs, delocalization and immigration in most advanced countries. ${ }^{1}$

Indeed, these policies, and the underlying views of the effects of offshoring and migration on labour market conditions are generally not empirically grounded. This is partially the result of difficulties at measuring the actual impact of these processes on jobs. While, on the one hand, offshoring some production activities, or hiring immigrant workers to perform them, directly reduces the demand for native workers; on the other hand such restructuring processes induce cost-savings as well as learning effects that improve the productivity, size and competitiveness of firms. This process may thus indirectly increase the demand for native workers, most likely in tasks complementary to those offshored or taken up by immigrant workers.

Most of the literature analyzing the effects of offshoring on employment has taken a macro perspective. In particular, this literature has widely analyzed the implications of service offshoring for total employment (Amiti and Wei 2005; OECD 2007) and for its composition by skill and occupation (Blinder 2006, 2009; Crinò 2010). Overall, the results suggest that service offshoring exerts modest effects on total employment, and that some less skilled and more easily tradable occupations may be relatively more at risk of relocation. These findings have been broadly confirmed by a few studies based on firm-level data (Gorg and Hanley

\footnotetext{
${ }^{1}$ For instance, the trend towards more favourable regulation for foreign investors that was observed in the 1990's seems to have arrested at the turn of the new century. The share of less favourable regulatory changes introduced by national governments vis a vis foreign investors has monotonically increased from $6 \%$ of all the 81 legal measures modified by 46 countries in year 2000 , to $27 \%$ of the 87 measures introduced by 59 countries in 2013 (UNCTAD 2014 p. 106). Other studies analyze patterns in public opinion on migration and find that, across countries of different income levels, only a small minority of voters favour more open migration policies. Facchini and Mayda (2012) suggest that the labour market competition threat perceived by skilled natives in the host countries might be driving the observed cautious policies.
} 
2005; Hijzen et al. 2011). Crinò (2009) and Feenstra (2010) provided well organized and updated surveys of the literature.

The literature on the microeconomic implications of service offshoring is instead much more limited. Only recently has research started investigating the effects of service offshoring on individual workers' wages (Geishecker and Görg 2013; Liu and Trefler 2008; Blinder and Krueger 2013) and probability of unemployment (Liu and Trefler 2008). Also in this case the effects have been found to be small, although some heterogeneity seems to exist across workers with different levels of education and with different occupations.

A growing number of papers has recently argued that the potential cost-savings associated with offshoring could reverse its direct displacement effect on employment and even generate a net increase in employment for native workers with low education levels (Grossman and Rossi-Hansberg 2008; Harrison and McMillan 2011; Baldwin and Robert-Nicoud 2014).

Peri and Sparber (2009) and Peri (2012)have found that immigration may increase demand for less educated native workers, particularly in tasks that are complementary to those taken up by immigrants.

A few works have jointly investigated the interactions among native, immigrant and offshore workers. In particular, Ottaviano et al. (2013) design a model of task assignment among heterogeneous native, immigrant and offshore workers and test this model to analyze the effects of immigration and offshoring on native workers in the US. They find that, within the manufacturing sector, immigrants do not compete much with natives, as these two groups of workers are relatively specialized in tasks at opposite ends of the skill intensity spectrum. Offshore workers, on the other hand, seem to be specialized in tasks of intermediate skill intensity. They also find that offshoring has no effect on native employment in the aggregate, while the effect of immigration on native employment is positive. This might suggest that offshoring and immigration improve industry efficiency, thereby creating new jobs.

Finally, most empirical studies have found negative wage effects from offshoring mainly for low-skilled and medium-skilled workers and in the manufacturing sector, although workers in offshoring firms whose jobs are not offshored may experience positive wage effects (see Harrison et al. 2011). The most recent empirical literature also considers the task content of jobs and finds that wage effects of offshoring can be heterogeneous within skill groups, depending on the ease at which individuals' tasks can be offshored (Hummels et al. 2014; Baumgarten et al. 2013; Ebenstein et al. 2014), with wage losses being more pronounced for routine tasks.

As regards the effects of immigration on local wages, the literature has shown that they depend on the skills of migrants and those of local workers, and particularly on the extent to which migrants have skills that are substitutes or complements to those of native workers (Borjas 2003). Immigration can increase competition for existing jobs but it can also create new jobs, thus short run supplyside negative effects may be mitigated by long run demand-side positive effects. Finally, recent research has also shown that while immigration appears to have a small impact on average wages, it has a more significant impact on wage distribution: low-paid workers lose while medium and high-paid workers may gain (Dustmann et al. 2013). 
Although the literature on the labour market effects of offshoring and immigration is rich and articulated, there are still relevant issues that need to be explored, especially when a micro-level perspective is adopted. First, even if wage and employment effects of offshoring and immigration are moderate, as suggested by most studies, effects on production might be relevant and also involve recomposition effects, leading to adjustments in production techniques within sectors and within firms. Second, while most of the studies focus on the effects of offshoring on individual or aggregate employment and wages, the effects of offshoreability, i.e. of potential offshoring or the "threat of being offshored", have not been studied as much. Third, the effects of offshoring on output and employment at home are inevitably mediated by the characteristics of institutions in general and of labour market institutions in particular. However, the specific role of institutions is still largely unexplored. Understanding this role requires a careful examination of micro-level governance of offshoring processes and is a prerequisite to the design of labour market regulations, structural measures and internationalisation policies that can tackle trade-offs offshoring generates.

This special section on "Offshoring and the labour market", draws on papers presented at the Final Conference held at Bocconi University, Milan, on September 24-25, 2013 on "Production, R\&D and knowledge offshoring: economic analyses and implications for Italy", with the aim to address some of the gaps discussed above. $^{2}$ In particular, the three articles selected for this Special Section investigate:

- The effect of immigration on firm performance.

- The effects of offshorability of tasks on wages.

- The moderating role of institutions in the relationship between offshoring and labour market.

The paper by De Arcangelis, Di Porto and Santoni, "Immigration and Manufacturing In Italy. Evidence from the 2000s" focuses on changes in production processes induced by globalising labour markets, and by inward flows of foreign workers in particular. The authors test for the effect of an increase in the migration rate on manufacturing firms' performance at the local level and on the production structure of Italian manufacturing. They develop and estimate a model for the Italian economy during the recent years of rapid and varied migration. Migrants' presence is found to positively affect firm's performance: doubling the number of migrants as a share of population at the province level raises sales per worker by 8-9\% on average, although this increase is unevenly distributed in low-tech versus high-tech sectors. On the labour supply side, low-skill migrants exert a higher effect on firms' performance than high-skill migrants.

\footnotetext{
2 The Conference and papers published here were based on a research project (prot. 2009KEKA5W), funded by the Italian Ministry of University and Research under the PRIN 2009 framework. A special issue has already been published in this journal on a related topic ("Offshoring and Innovation", Economia e Politica industrial/Journal of Industrial and Business Economics, n.1, 2015), focusing on the effects of offshoring on innovation capabilities and performance in the host and home economies, relying on other papers presented at the same PRIN Conference. See: Castellani, Mancusi, Santangelo and Zanfei (2015) for an introductory note on the links between offshoring and innovation.
} 
The paper by Brandle and Koch, "Offshoreability and Wages: Evidence from German Task Data", analyses the relationship between individuals' wages and the potential relocation of their jobs, which they measure through a large number of job characteristics. The authors distinguish between characteristics that are supposed to make a job more offshoreable, i.e. transferable across national borders, and characteristics that are assumed to make a job more easily outsourceable, i.e. transferable across a firm's boundary. Wages are found to be negatively influenced by these characteristics and appear significantly lower for individuals with easily offshoreable jobs. Results also show differences between blue-collar and whitecollar workers and between offshoreability in manufacturing and services.

Finally, the paper by Bramucci and Zanfei "The governance of offshoring and its effects at home: The role of codetermination in the international organization of German firms" focuses on the links between labour market institutions and offshoring. The authors here use case studies to illustrate how works councils deal with three important aspects of offshoring processes: the timeliness of information they receive from the management, the negotiation of compensation mechanisms and the design of alternative strategies. While the paper finds no evidence of works councils impeding offshoring, there are elements suggesting that they may influence the way such decisions are taken, and moderate their effects on employment in the home country.

\section{References}

Amiti, M., \& Wei, S. J. (2005). Fear of service outsourcing: Is it justified? Economic Policy, 20(42), 308-347.

Baldwin, R, \& Robert-Nicoud, F. (2014). Trade-in-goods and trade-in-tasks: An integrating framework. Journal of International Economics, 92(1), 51-62.

Baumgarten, D., Geishecker, I., \& Görg, H. (2013). Offshoring, tasks, and the skill-wage pattern. European Economic Review, 61, 132-152.

Blinder, A. S. (2006). Offshoring: The next industrial revolution? Foreign Affairs, 85(2), 113-128.

Blinder, A. S. (2009). How many U.S. jobs might be offshorable? World Economics, 10(2), 41-78.

Blinder, A. S., \& Krueger, A. B. (2013). Alternative measures of offshorability: A survey approach. Journal of Labor Economics, 31(S1), S97-S128.

Borjas, G. (2003). The labor demand curve is downward sloping: reexamining the impact of immigration on the labor market. Quarterly Journal of Economics, 118(4), 1335-1374.

Castellani, D., Mancusi, M. L., Santagelo, M. D., \& Zanfei, A. (2015). Exploring the links between offshoring and innovation. Economia e Politica Industriale, 42(1), 1-8.

Crinò, R. (2009). Offshoring, multinationals and labour market: A review of the empirical literature. Journal of Economic Surveys, 23(2), 197-249.

Crinò, R. (2010). Service offshoring and white-collar employment. Review of Economic Studies, 77(2), 595-632.

Dustmann, C., Frattini, T., \& Preston, I. P. (2013). The effect of immigration along the distribution of wages. Review of Economic Studies, 80(1), 145-173.

Ebenstein, A., Harrison, A., McMillan, M. \& Phillips, S. (2014). Estimating the impact of trade and offshoring on American workers using the current population surveys. Review of Economics and Statistics, 96(4), 581-595.

ETAN. (1998). Technology policy in the context of internationalisation of $R \& D$ and innovation. How to strengthen Europe's competitive advantage in technology. Brussels: European Commission, Directorate-General Science, Research and Development. 
Facchini, G., \& Mayda, A. M. (2012). Individual attitudes towards skilled migration: An empirical analysis across countries. The World Economy, 35(2), 183-196.

Feenstra, R., \& Hanson, G. (1997). Foreign direct investment and relative wages: Evidence from Mexico's Maquiladoras. Journal of International Economics, 42(3), 371-393.

Feenstra, R. (2010). Offshoring in the Global Economy. MIT Press, Cambridge, Massachusetts.

Geishecker, I., \& Görg, H. (2013). Service offshoring and wages: Evidence from micro data. Oxford Economic Papers, 65(1), 124-146.

Gorg, H., \& Hanley, A. (2005). Labour demand effects of international outsourcing: Evidence from plantlevel data. International Review of Economics and Finance, 14(3), 365-376.

Grossman, G., \& Rossi-Hansberg, E. (2008). Trading tasks: A simple theory of offshoring. American Economic Review, 98(5), 1978-1997.

Harrison, A., McLaren, J., \& McMillan, M. (2011). Recent perspectives on trade and inequality. Annual Review of Economics, 3(1), 261-289.

Harrison, A., \& McMillan, M. (2011). Offshoring jobs? Multinational and U.S. manufacturing employment. Review of Economics and Statistics, 93(3), 857-875.

Hijzen, A., Pisu, M., Upward, R., \& Wright, P. (2011). Employment, job turnover, and trade in producer services: UK firm-level evidence. Canadian Journal of Economics, 44(3), 1020-1043.

Hummels, D., Jørgensen, R., Munch, J., \& Xiang, C. (2014). The wage effects of offshoring: Evidence from Danish matched worker-firm data. American Economic Review, 104(6), 1597-1629.

Kaldor, M., Anheier, H., \& Glasius, M. (Eds.) (2003). Global civil society in an era of regressive globalisation. In LSE. Global civil society 2003 (pp. 3-33). Oxford: Oxford University Press.

Kotabe, M. (1990). The relationship between offshore sourcing and innovativeness of US multinational firms: an empirical investigation. Journal of International Business Studies, 21(4), 623-638.

Levinson, M. (2011). Hollowing out in U.S. manufacturing: Analysis and issues for congress, CRS, Washington DC, R41712, www.crs.gov.

Liu, R., \& Trefler, D. (2008). Much ado about nothing: American jobs and the rise of service outsourcing to China and India, NBER working paper 14061.

Oecd. (2007). Offshoring and employment: Trends and impacts. Paris: Oecd.

Okkerse, L. (2008). How to measure labour market effects of immigration: A review. Journal of Economic Surveys, 22(1), 1-30.

Ottaviano, G., Peri, G., \& Wright, G. (2013). Immigration, offshoring and American jobs. American Economic Review, 103(5), 1925-1959.

Peri, G. (2012). The effect of immigration on productivity: Evidence from U.S. states. Review of Economics and Statistics, 94(1), 348-358.

Peri, G., \& Sparber, C. (2009). Task specialization, immigration and wages, American Economic Journal: Applied Economics, 1(3), 135-169.

Unctad. (2014). World investment report. Geneva: United Nations. 